\title{
Analisis Kemampuan Numerik Siswa SMP Negeri Di Kota Kendari Ditinjau Dari Perbedaan Gender
}

\author{
(An Analysisof Students Number Senseinpublic Junior High School At Kendari City \\ Viewed From Gender Differences)
}

\author{
Sitriani $^{1}$, Kadir $^{2}$, La Arapu $^{3}$, La Ndia $^{3}$ \\ ${ }^{1}$ Alumnus Jurusan Pendidikan Matematika FKIP Universitas Halu Oleo; Co-author: \\ sitriani.rooly@gmail.com \\ ${ }^{2}$ Dosen Pendidikan Matematika FKIP dan PPS Universitas Halu Oleo \\ ${ }^{3}$ Dosen Pendidikan Matematika FKIP Universitas Halu Oleo
}

\begin{abstract}
Abstrak: Rendahnya kemampuan numerik siswa SMP Negeri Di Kota Kendari. Populasi penelitian ini tersebar pada 20 SMP Negeri di kota Kendari.Penentuan sampel dilakukan dengan teknik Cluster Sampling (Area Sampling) dan simple random sampling. Sampel yang digunakan adalah siswa kelas VIII dari 6 SMP Negeri Kendari yang diambil dari 6 kecamatan yang berbeda. Teknik analisis data menggunakan statistik deskriptif dan statistik inferensial. Berdasarkan hasil penelitian, diperoleh kesimpulan berikut: (1) Rata-rata kemampuan numerik siswa laki-laki adalah $36,11,96,34 \%$ atau 158 siswa mempunyai kemampuan numerik rendah dan 3,66\% atau 6 siswa mempunyai kemampuan numerik sedang. (2) Rata-rata kemampuan numerik siswa perempuan adalah 40, 92,05\% atau 197 siswa mempunyai kemampuan numerik rendah, 7,48\% atau 16 siswa yang mempunyai kemampuan numerik sedang dan $0,46 \%$ atau 1 siswa mempunyai kemampuan numerik tinggi. (3) Hasil analisis inferensial menunjukkan bahwa terdapat perbedaan yang signifikan antara kemampuan numerik siswa laki-laki dan kemampuan numerik perempuan pada SMP Negeri di Kota Kendari.
\end{abstract}

Kata kunci: kemampuan numerik, matematika dan gender.

\begin{abstract}
The low number sense of students in Public Junior High School in Kendari city. The population of this study was spread in 20 Public Junior High Schools in Kendari city. Determination of the sample is done by Cluster Sampling technique (Area Sampling) and simple random sampling. The sample used was grade VIII students from 6 Public Junior High Schools in Kendari city taken from 6 different sub-districts. The data analysis technique uses descriptive statistics and inferential statistics. Based on the results of the study, the following conclusions were obtained: (1) The average numerical ability of male students was $36.11,96.34 \%$ or 158 students had low numerical abilities and $3.66 \%$ or 6 students had moderate numerical abilities. (2) The average numerical ability of female students is $40,92.05 \%$ or 197 students have low numerical abilities, $7.48 \%$ or 16 students who have moderate numerical abilities and $0.46 \%$ or 1 student has high numerical abilities. (3) The results of inferential analysis show that there is a significant difference between male students' numerical abilities and women's numerical abilities in state junior high schools in Kendari City.
\end{abstract}

Keywords: Number Sense, mathematics, and Gender.

\section{PENDAHULUAN}

Matematika

merupakan

keterampilan dasar dalam kehidupan dan aplikasinya yang bertebaran di seluruh lapisan masyarakat. Menurut Siagian (2013: 125), matematika merupakan suatu cara atau teknik yang digunakan dalam berpikir logis. Kebenaran dalam matematika merupakan kebenaran yang berdasarkan logika bukan empiris atau kenyataan. Secara teoretis matematika adalah ilmu yang bertujuan mendidik siswa agar dapat berpikir secara logis, kritis, rasional, dan percaya diri sehingga mampu membentuk kepribadian yang mandiri, kreatif serta mempunyai kemampuan dan keberanian dalam menghadapi masalah-masalah dalam kehidupan sehari-hari.

Salah satu faktor yang mempengaruhi keberhasilan siswa dalam menguasai matematika adalah kemampuan numerik. Kemampuan numerik merupakan 
kemampuan khusus dalam hitung menghitung. Kemampuan numerik mempengaruhi kemampuan siswa dalam memahami dan menyelesaikan soal matematika. Menurut Leoni (2008: 1), kemampuan numerik yaitu kemampuan yang berhubungan dengan angka dan kemampuan untuk berhitung. Kemampuan numerik siswa berbeda-beda. Ada siswa yang memiliki kemampuan numerik yang tinggi dan rendah. Siswa yang mempunyai kemampuan numerik yang tinggi akan bekerja lebih baik dalam berhitung. Sedangkan siswa yang mempunyai kemampuan numerik rendah akan mengalami kesulitan dalam berhitung. Beberapa hasil penelitian mengemukakan bahwa siswa yang mempunyai kemampuan numerik tinggi dan belajar dengan cara yang benar dan tepat akan mampu mengembangkan konsep baru dengan memadukan berbagai konsep dasar sebagai pendukung untuk menyelesaikan masalah, karena dalam diri siswa tersebut terdapat ketekunan, keuletan, kekerasan hati, minat, keingintahuan dan daya cipta (hal yang menumbuhkan kesadaran kekuatan matematika).

Berikut beberapa pakar yang memberikan pendapat tentang definisi kemampuan numerik (number sense)yang terdapat dalam bukunya Saleh (2009).

1. Fennel dan Landis (1994: 187) mendefinisikan "Number sense sebagai sebuah kesadaran dan pemahaman seseorang mengenai bilangan, hubungan antar bilangan, tingkat kepentingannya, dan perhitungannya dengan menggunakan mental matematika".

2. Burton (1993), menyatakan bahwa "Number sense adalah cara pandang seseorang terhadap suatu bilangan beserta perhitungannya. Ia melakukan berbagai cara dan strategi untuk meyelesaikan persoalan yang rumit".

3. Howden (1989: 6), mengemukakan bahwa "Number sense adalah suatu penjelajahan menempatkannya dalam suatu masalah, dan menghubungkan keduanya tanpa dibatasi oleh algoritme yang kuno".

4. Gersten \& Chard (1999: 18), berpendapat bahwa "Number sense adalah kebebasan dan perasaan anakanak terhadap suatu bilangan. Hal ini bisa mengasah kemampuan untuk mengembangkan mental matematika".

5. Bobis (1996: 17), mengartikan "Number sense adalah suatu konsep yang ter-organisasi mengenai suatu bilangan". Hal ini bisa membantu siswa untuk menyelesaikan masalahnya tanpa harus mengacu pada algoritma".

6. Rey dan Yang (1998: 39) mendefinisikan number sense sebagai berikut: Number sense mengacu pada pemahaman umum seseorang tentang bilangan dan operasinya disertai dengan kemampuan dan kecenderungan untuk menggunakan pemahamannya ke dalam cara yang fleksibel untuk membuat pertimbangan matematika serta untuk mengembangkan penggunaan dan strategi keefisienan untuk mungelola situasi numerik.

Kesimpulan yang dapat ditarik dari berbagi definisi kemampuan numerik di atas bahwa kemampuan numerik merupakan sebuah kesadaran dan pemahaman umum seseorang mengenai bilangan dan operasinya, serta kecakapannya dalam menyelesaikan pertanyaan yang berkaitan tentang bilangan. Jika kemampuan numerik siswa dikembangkan dengan baik maka siswa dapat menggunakan angka sebagai referensi untuk mencari solusi dari permasalahan yang dihadapi. Elemen kunci dari number sense pada siswa mencakup kemampuan berpikir dengan jumlah kecil, kemampuan membedakan pengolahan bilangan, kemampuan dalam menghitung, membandingkan besaran, dan melakukan transformasi bilangan sederhana.

Kemampuan numerik setiap anak itu berbeda-beda. Ada anak yang begitu 
tinggi kemampuan numeriknya namun ada juga yang sebaliknya dan hal tersebut berpengaruh dalam jalannya pembelajaran. Pada kenyataanya sebagian siswa mengeluh kesulitan mempelajari matematika karena matematika tidak hanya sekedar menguasai konsep tetapi juga harus menghitung dengan rumusrumus. Tidak sedikit siswa yang menguasai konsep tetapi ketika mereka sudah mendapati permasalahan dalam bentuk hitungan mereka kesulitan mengerjakannya.
McIntosh, Reys and Reys (1999: 61) mengembangkan sebuah kerangka (indikator) yang dapat digunakan untuk menilai kemampuan number sense. Kerangka ini tidak melihat faktor yang dapat mempengaruhi kemampuan number sense, tetapi dapat dijadikan tolak ukur untuk melihat atau menilai kemampuan number sense yang dimiliki siswa. Indikator tersebut dirumuskan sebagai berikut.

Tabel 1. Indikator Kemampuan Numerik

\begin{tabular}{|c|c|c|}
\hline Indikator & \multicolumn{2}{|c|}{ Sub Indikator } \\
\hline \multirow{13}{*}{$\begin{array}{l}\text { 1. Pengetahuan dan } \\
\text { Pemahaman } \\
\text { tentang Bilangan }\end{array}$} & \multirow{2}{*}{ 1.1 Urutan Bilangan } & 1.1.1 Nilai Tempat \\
\hline & & 1.1.2.Hubungan Antar Tipe \\
\hline & & 1.1.3 Mengurutkan \\
\hline & & Menurut Jenisnya \\
\hline & & 1.2.1 Grafis/Simbol \\
\hline & 1.2. Representasi Bentuk & 1.2.2 Kesetaraan Bentuk Bilangan \\
\hline & Bilangan & $\begin{array}{l}\text { 1.2.3 Perbandingan dengan Tolak } \\
\text { Ukur }\end{array}$ \\
\hline & & 1.3.1 Membandingkan \\
\hline & 1.3 Relativitas Dan Besaran & Referensi Fisik \\
\hline & Mutlak Bilangan & 1.3.2 Membandingkan \\
\hline & & Referensi Matematika \\
\hline & 14 Sistem Tolak Ukur & 1.4.1 Matematika \\
\hline & 1.4 Sistem 1 огак UKur & 1.4.2 Personal \\
\hline & & 2.1.1 Operasi pada Bilangan Asli \\
\hline & 2.1 Memahami Operasi & $\begin{array}{l}\text { 2.1.2 Operasi pada Bilangan } \\
\text { Pecahan }\end{array}$ \\
\hline & & 2.2.1 Sifat Komutatif \\
\hline & & 2.2.2 Sifat Asosiatif \\
\hline 2. Pengetahuan dan & 2.2.Memahami & 2.2.3 Sifat Distributif \\
\hline Pemahaman & & 2.2.4 Elemen Identitas \\
\hline & & 2.2.5 Elemen Invers \\
\hline & & 2.3.1 Penjumlahan/Perkalian \\
\hline & 2.3.Memahami & 2.3.2 Pengurangan/Pembagian \\
\hline & Antar Operasi & 2.3.3 Penjumlahan/Pengurangan \\
\hline & & 2.3.4 Perkalian/Pembagian \\
\hline 3. Menerapkan & 3.1. Memahami Hubungan & 3.1.1. Mengenali Data Sebagai Bil. \\
\hline Pengetahuan dan & Antara Konteks Masalah dan & Tepat atau Aproksimasi \\
\hline Pemahaman & Perhitungan yang Diperlukan & 3.1.2. Kesadaran yang Mungkin Bil. \\
\hline
\end{tabular}




\begin{tabular}{|c|c|c|}
\hline Indikator & \multicolumn{2}{|c|}{ Sub Indikator } \\
\hline \multirow{9}{*}{$\begin{array}{l}\text { tentang Bilangan } \\
\text { dan Operasi } \\
\text { Kedalam } \\
\text { Pengaturan } \\
\text { Komputasi }\end{array}$} & & Tepat atau Aproksimasi \\
\hline & & 3.2.1.Kemampuan \\
\hline & & Menciptakan Strategi \\
\hline & Kesadaran & 3.2.2.Kemampuan \\
\hline & Beberapa Strategi & $\begin{array}{l}\text { Menerapkan Strategi yang Berbeda } \\
\text { 3.2.3 Kemampuan untuk Memilih } \\
\text { Strategi yang Efisien }\end{array}$ \\
\hline & & 3.3.1 Fasilitas dengan Berbagai \\
\hline & $\begin{array}{l}\text { 3.3. Kecenderungan Untuk } \\
\text { Menggunakan Representasi }\end{array}$ & $\begin{array}{l}\text { Metode (Mental, Kalkulator, } \\
\text { Pensil/Kertas) }\end{array}$ \\
\hline & atau Metode yang Efisien & $\begin{array}{l}\text { 3.3.2 Fasilitas Memilih Bilangan } \\
\text { yang Efisien }\end{array}$ \\
\hline & $\begin{array}{l}\text { 3.4. Kecendrungan untuk } \\
\text { Meninjau Data dan Hasil } \\
\text { untuk Sensibilitas }\end{array}$ & $\begin{array}{l}\text { 3.4.1 Mengenali Data yang Masuk } \\
\text { Akal } \\
\text { 3.4.2 Mengenali Kalkulasi yang } \\
\text { Masuk Akal }\end{array}$ \\
\hline
\end{tabular}

Indikator tersebut kemudian dirumuskan menjadi six number sense strands dengan rincian sebagai berikut.

a. understanding and use of the meaning and size of numbers (pemahaman tentang pengertian dan nilai dari bilangan)

b. understanding and use of equivalent forms and representations of numbers (pemahaman tentang bagaimana menggunakan bentuk ekuivalen dan representasi urutan dari bilangan)

c. understanding the meaning and effect of operations (pemahaman arti dan pengaruh dari mengoperasikan suatu bilangan)

d. understanding and use of equivalent expressions (pemahaman dan kegunaan dari pernyataan yang ekuivalen)

e. computing and counting strategies (Perhitungan dan strategi menghitung)

f. measurement benchmarks. (tolak ukur pengukuran)

Lebih lanjut McIntosh (1999: 61) memberikan catatan bahwa untuk mengukur kemampuan number sense anak hanya menggunakan five number sense strands sebagai indikator dalam membuat soal. Sedangkan untuk six number sense strands digunakan untuk mengukur anak yang memiliki kemampuan atau jenjang pendidikan yang lebih tinggi.

Faktor lain yang harus diperhatikan dalam mempelajari matematika yang tak kalah pentingnya adalah faktor gender. Perbedaan gender tentu memengaruhi perbedaan psikologis dalam belajar, sehingga siswa laki-laki dan perempuan tentu memiliki banyak perbedaan dalam mempelajari matematika. Menurut Crawford, gender adalah serangkaian karakteristik dan sifat yang secara sosiokultural dilekatkan kepada laki-laki dan perempuan. Blakemore, Berenbaum, dan Liben mendefinisikan gender sebagai karakteristik pembeda antara laki-laki dan perempuan yang bukan berdasarkan pada biologis dan bukan bersifat kodrati, tetapi berdasarkan pada kebiasaan atau karakteristik sosiokultural masyarakat yang membentuknya (Herdiansyah, 2016: 4). Karakteristik atau sifat yang dilekatkan tersebut diciptakan oleh social atau budaya sekitar. Contoh karakteristik tersebut antara lain; laki-laki adalah jenis manusia yang kuat, perkarasa dan tidak cengeng, rasional, logis dan sebagainya. Sementara perempuan adalah jenis manusia yang lemah, emosional, cengeng, keibuan, lembut, penuh empati, perhatian, dan lain sebagainya. Dikarenakan oleh 
karakteristik tersebut seringkali dalam proses pembelajaran matematika laki-laki dan perempuan ditempatkan dalam wilayah yang berbeda.

Di beberapa Negara di dunia, perempuan dianggap memiliki kekuasaan dan status yang lebih rendah dibandingkan laki-laki. Dibandingkan laki-laki, perempuan lebih banyak melakukan tugastugas rumah tangga, kurang banyak menggunakan waktunya untuk untuk dirinya sendiri seperti belajar. Singh (2008: 42) menyatakan adanya keterkaitan antara perbedaan jenis kelamin dengan kemampuan number sense seperti berikut ini:

"male students seemed to perform better than their female counterparts across the ages (all levels) although the difference was only significant among the 13 year old students (Form 1). This result does not deal with the findings of recent research (Isiksal \& Cakiroglu, 2008; Hyde and Linn, 2006; Ma, 2004; Awang \& Ismail, 2003). However, previous research (Fennema \& Carpenter, 1981; Walden and Walkerdine, 1982; Battista, 1990) has indicated that males were deemed to do better at mathematics when spatial ability is required and this conforms with their findings since number sense is

\section{METODE PENELITIAN}

Penelitian ini adalah penelitian deskriptif eksploratif yang menggunakan deskriptif kuantitatif dan kualitatif. Pengambilan data penelitian ini dilakukan dengan menggunakan tes dan wawancara. Perhatian utama dalam penelitian ini adalah hasil teskemampuan numerik siswa. Analisis hasil tes dan angket siswa tersebut menyajikan jawaban terhadap permasalahan penelitian ini.Penelitian ini dilaksanakan pada beberapa SMP Negeri di Kota Kendari yaitu SMP Negeri 1 Kendari, SMP Negeri 3 Kendari, SMP involved quite heavily in visualizing and spatial ability."

Penelitian ini dilakukan pada siswa dengan rentang usia 13-16 tahun, perbedaan kemampuan number sense terlihat jelas pada usia 13 tahun. Pernyataan tersebut juga dibenarkan oleh beberapa pakar seperti Battista, Walden, dan Carpenter yang tercantum dalam tulisannya. Callahan dan Reis (1996) memberikan pernyatan tentang perbedaan kemampuan antara siswa perempuan dan laki-laki dari hasil penelitiannya sebagai berikut. Pada masa kanak-kanak awal hingga masuk sekolah dasar, siswa lakilaki berbakat dan perempuan berbakat memiliki jumlah yang relatif sama. Sedangakan pada masa ramaja terjadi penurunan, pada sekitar usia dua belas tahun siswa laki-laki berbakat berjumlah lebih banyak dari siswa perempuan berbakat, dan pada masa dewasa perbandingan jumlah antara laki-laki berbakat menjadi sangat berbeda. Pada penelitian ini peneliti mengambil jenjang SMP karena pada jenjang tersebut perbedaan kemampuan number sense terlihat jelas seperti yang sudah dipaparkan sebelumnya. Pada jenjang ini sangat baik untuk memperkuat fondasi dan pengalaman number sense yang dimiliki siswa.

Negeri 4 Kendari, SMP Negeri 5 Kendari, SMP Negeri 8 Kendari, dan SMP Negeri 9 Kendari. Waktu pelaksanaan penelitian ini pada semester ganjil tahun ajaran 2018/2019.

Populasi dalam penelitian ini adalah siswa SMP Negeri di Kota Kendari. Populasi pada penelitian ini tersebar pada 20 SMP Negeri di Kota Kendari. Teknik sampling pada penelitian ini yaitu Cluster sampling dan simple random sampling. Sampel yang digunakan adalah siswa kelas VIII dari 6 SMP Negeri yang diambil dari 
6 kecamatan yang berbeda yang terdapat di kota Kendari. Jadi, sampel pada penelitian ini adalah siswa kelas VIII dari SMP Negeri 1 Kendari kec. Kendari Barat, SMP Negeri 3 Kendari kec. Puuwatu, SMP Negeri 4 Kendari kec. Wua-wua, SMP Negeri 5 Kendari kec. Poasia, SMP Negeri 8 Kendari kec. Mandonga, SMP Negeri 9 Kendari kec. Kadia. Pada setiap sekolah yang diteliti tersebut dipilih dua kelas untuk mewakili keseluruhan kelas VIII di sekolah tersebut. Jadi, terdapat duabelas kelas yang berperan sebagai sampel dalam penelitian ini.

Instrumen yang digunakan untuk melengkapi data dan membandingkan data yang telah ditemukan yaitu tes kemampuan numerik yang digunakan untuk mengetahui kemampuan numerik siswa laki-laki dan siswa perempuan yang berkaitan dengan hitung-menghitung, komparasi kuantitatif, dan penerapan konsep matematika. Tes dalam penelitian ini berjumlah 40 butir soal dalam bentuk pilihan ganda yang disusun oleh peneliti dan dikonsultasikan dengan dosen pembimbing.Dan pedoman wawancara digunakan sebagai alat untuk mengetahui kendala yang terkait dengan persoalan siswa dalam menyelesaikan soal-soal kemampuan numerik. Pedoman wawancara digunakan sebagai alat untuk mengetahui kendala yang terkait dengan persoalan siswa dalam menyelesaikan soal-soal kemampuan numerik

Sebelum pedoman tes yang berupa soal-soal tes ini digunakan, terlebih dahulu peneliti mengujicobakannya untuk memastikan validitas dan reliabilitas instrumen tes kemampuannumerik. Sehingga diharapkan soal yang digunakan benar-benar dapat mengukur kemampuannumerik siswa.

Uji validitas dan reliabilitas instrumen penelitian yang dilakukan dalam penelitian ini adalah uji coba. Analisis validitas penilaian uji coba digunakan untuk mengetahui validitas konsep instrumen melalui penilaian uji coba dengan menggunakan rumus korelasi Product-Moment. Uji coba instrumen dilakukan kepada 66 orang siswa di SMP Negeri 2 Kendari, dikelas VIII $_{\mathrm{A}}$ dan $\mathrm{VIII}_{\mathrm{G}}$. Uji coba instrumen dilakukan untuk melihat validitas butir tes dan reliabilitas tes.

Berdasarkan hasil analisis tingkat reliabilitas instrumen, diperoleh reliabilitas untuk instrumen tes Kemampuan Numerik adalah 0,710 berkategori tinggi. Jadi, dapat disimpulkan bahwa 37 nomor soal dari instrumen yang diuji cobakan memenuhi kriteria. Artinya, instrumen tersebut dapat digunakan sebagai alat ukur untuk mengukur apa yang hendak diukur.

Pengumpulan data dalam penelitian ini dilakukan menggunakan teknik pemberian tes dan wawancara. Tes yang dilakukan dalam penelitian ini adalah tes tertulis yang berbentuk pilihan ganda dan berjumlah 40 butir soal. Tes disusun oleh peneliti dan dikonsultasikan dengan guru dan kedua dosen pembimbing. Tes bertujuan untuk mengetahui tentang kemampuan numerik siswa.

Wawancara yang dilakukan dalam penelitan ini adalah wawancara guru dan siswa. Wawancara dengan guru dimaksudkan untuk mengecek berbagai kendala terkait dengan persoalanpersoalan mengenai kemampuan numerik. Guru yang diwawancarai mewakili sekolah yang dijadikan sampel penelitian dan sedapat mungkin mengetahui secara lengkap permasalahan yang dihadapi siswa dalam menyelesaikan soal-soal yang berkaitan dengan kemampuan numerik.

Analisis data dalam penelitian ini dilakukan dengan menggunakan dua jenis analisis, yaitu analisis deskriptif dan analisis inferensial. Analisis deskriptif dimaksudkan untuk mendeskripsikan hasil belajar matematika siswa melalui nilai rata-rata $(\mathrm{x})$, median $(\mathrm{Me})$, modus (Mo), varians $\left(\mathrm{S}^{2}\right)$, standar deviasi $(\mathrm{S})$, nilai maksimum $\left(X_{\max }\right)$, dan nilai minimum $\left(X_{\text {min }}\right)$ serta persentase kemampuan numerik siswa. Penyajian hasil analisis 
desktiptif diperoleh dengan bantuan Microsoft Excel. Analisis inferensial dilakukan untuk menguji hipotesis penelitian. Sebelum dilakukan pengujian hipotesis terlebih dahulu dilakukan uji normalitas dan uji homogenitas sebagai prasyarat untuk pengujian hipotesis. Selain secara manual, uji-t juga dapat dilakukan dengan bantuan SPSS digunakan Independent Samples $t$ Test. Apabila data tidak berdistribusi normal maka uji yang digunakan adalah uji non parametrik untuk

\section{HASIL PENELITIAN}

Berdasarkan hasil analisis data tes kemampuan numerik siswa pada pelajaran matematika yang diperoleh melalui soal kemampuan numerik, statistik deskriptif perbedaan rata-rata yakni uji Mann Whitney. Kriteria pengambilan keputusan jika nilai sig $\geq 0,05$, maka $\mathrm{H}_{0}$ diterima atau tidak ada perbedaan yang signifikan antara kemampuan numerik siswa laki-laki dan siswa perempuan pada SMP Negeri di Kota Kendari. Sebaliknya, jika sig < 0,05 maka $\mathrm{H}_{0}$ ditolak atau ada perbedaan yang signifikan antara kemampuan numerik siswa laki-laki dan siswa perempuan pada SMP Negeri di Kota Kendari.

kemampuan numerik siswa pada pelajaran matematika siswa SMP Negeri di Kota Kendari tahun ajaran 2018/2019 tersaji pada Tabel 2.

Tabel 2. Deskripsi Kemampuan Numerik Siswa Laki-Laki dan Perempuan

\begin{tabular}{llllllll}
\hline Jenis Kelamin & N & Rata-Rata & Min & Maks & Modus & Median & $\begin{array}{c}\text { Standar } \\
\text { Deviasi }\end{array}$ \\
\hline L & 164 & 36,11 & 8,11 & 75,68 & 32,43 & 33,78 & 13,65 \\
P & 214 & 40 & 13,51 & 91,89 & 56,76 & 37,84 & 15,13 \\
L\&P & 378 & 38,43 & 8,11 & 91,89 & 35,14 & 37,84 & 14,63 \\
\hline
\end{tabular}

Sumber: Data diolah menggunakan Microsoft Excel 2010

Tabel 2 menunjukkan rata-rata nilai minimum, nilai maksimal, dan median kemampuan numerik siswa perempuan lebih tinggi dibandingkan kemampuan numerik siswa laki-laki.

Tabel 3. Persentase Kemampuan Numerik Siswa Laki-Laki dan Siswa Perempuan

\begin{tabular}{lllcc}
\hline \multicolumn{2}{c}{$\begin{array}{c}\text { Kategori Kemampuan } \\
\text { Numerik }\end{array}$} & Frekuensi & Jumlah & $\begin{array}{c}\text { Presentase } \\
(\%)\end{array}$ \\
\hline Tinggi & L & 0 & 1 & 0,265 \\
Sedang & P & 1 & 22 & 5,820 \\
\multirow{2}{*}{ Rendah } & L & 6 & & \\
& P & 16 & 355 & 93,915 \\
\hline
\end{tabular}

Sumber: Data diolah dengan mengunakan Microsoft Excel 2010

Tabel 3 menunjukkan bahwa terdapat 1 orang siswa perempuan yang memiliki kemampuan numerik dengan kategori tinggi, 22 siswa memiliki kemampuan numerik pada kategori sedang yaitu 6 orang siswa laki-laki dan 16 siswa perempuan, dan 355 siswa memiliki kemampuan numerik dengan kategori rendah terdiri dari 158 siswa laki-laki dan 197 siswa perempuan. Hal ini menunjukkan bahwa kemampuan numerik siswa kelas VIII di SMP Negeri di Kota Kendari adalah tergolong rendah.

Sebelum dilakukan pengujian hipotesis terlebih dahulu dilakukan uji normalitas dan uji homogenitas. Uji 
normalitas data dilakukan untuk mengetahui apakah data berasal dari populasi yang berdistribusi normal atau tidak. Uji homogenitas dilakukan untuk mengetahui apakah varians dari kedua data homogen atau tidak. Hal tersebut dilakukan untuk keperluan penentuan uji hipotesis yang akan dipilih.

Berikut ini adalah hasil perhitungan uji normalitas Kolmogorov-Smirnov melalui bantuan aplikasi SPSS yang disajikan pada Tabel 4.

Tabel 4. Hasil Analisis Statistik Uji Normalitas Data Menggunakan KolmogorovSmirnov

\begin{tabular}{llll}
\hline & & Laki laki & Perempuan \\
\hline $\mathrm{N}$ & & 164 & 214 \\
Normal & Rata-rata & 36,1074 & 40,2122 \\
Parameters $^{\text {a }}$ & Std. Deviation & 13,65 & 15,12739 \\
& & & \\
Kolmogorov-Smirnov Z & 1,359 & 1,071 \\
Asymp. Sig. (2-tailed) & 0,05 & 0,201 \\
\hline
\end{tabular}

Sumber: Data diolah menggunakan SPSS

Berdasarkan hasil analisis pada Tabel 4, dapat dilihat bahwa nilai Asymp. Sig. (2-tailed) untuk siswa laki-laki sebesar 0,05 nilai ini sama dengan $\alpha=0,05$, maka $H_{0}$ ditolak. Hal ini berarti bahwa data sampel yang diteliti berasal dari populasi yang tidak berdistribusi normal.

\section{Tabel 5. Hasil Analisis Statistik Uji Homogenitas Data Menggunakan Uji Levene}

\begin{tabular}{cccc} 
Levene Statistic & df1 & df2 & Sig. \\
2,893 & 1 & 376 & 0,09 \\
\hline Sumber: Data diolah menggunakan & SPSS
\end{tabular}

Dari Tabel 5 di atas terlihat bahwa nilai signifikan statistik uji Levene adalah 0,090. Nilai signifikan ini lebih besar dari taraf signifikan 0,05 ( nilai sig. $(0,090)>\alpha$ $=0,05)$, maka $\mathrm{H}_{0}$ diterima. Ini berarti bahwa varians data kemampuan numerik siswa laki-laki homogen dengan kemampuan numerik siswa perempuan.

Setelah mengetahui bahwa data kemampuan numerik siswa laki-laki dan perempuan tidak berdistribusi normal dan memiliki varians yang homogen, maka tahap selanjutnya adalah melakukan pengujian hipotesis.Karenatidak berdistribusi normal maka data kemampuan numerik siswa laki-laki dan perempuan diuji menggunakan statistika non parametrik yakni menggunakan uji Mann Whitney dengan bantuan SPSS.

Berikut hipotesis statistik:

$$
\mathrm{H}_{0}: \mu_{1}=\mu_{2} \quad \text { vs } \quad \mathrm{H}_{1}: \mu_{1} \neq \mu_{2}
$$

Keterangan:

$\mu_{1}=$ rerata nilai kemampuan numerik siswa laki-laki pada SMP Negeri di Kota Kendari.

$\mu_{2}=$ rerata nilai kemampuan numerik siswa perempuan pada SMP Negeri di Kota Kendari.

$\mathrm{H}_{0}=$ tidak ada perbedaan yang signifikan kemampuan numerik siswa laki-laki dan perempuan pada SMP Negeri di Kota Kendari. 
$\mathrm{H}_{1}=$ ada perbedaan yang signifikan kemampuan numerik siswa laki-laki dan perempuan pada SMP Negeri di Kota Kendari.
Hasil pengujian hipotesis penelitian ini disajikan pada Tabel 6.

Tabel 6. Hasil Analisis Statistik Uji Hipotesis Data Menggunakan Uji Mann Whitney Mann-Whitney U Asymp. Sig. (2-tailed)

$\frac{14810,5}{\text { Sumber: Data diolah menggunakan SPSS }}$

Berdasarkan hasil pengujian Mann Whitney pada kemampuan numerik siswa laki-laki dan perempuan yang tersaji pada Tabel 7, diperoleh bahwa nilai Sig. (2tailed) $=0,009<0,05=\alpha$. Ini berarti $H_{0}$ ditolak. Dengan demikian, dapat disimpulkan bahwa ada perbedaan yang

\section{PEMBAHASAN}

Berdasarkan uraian hasil analisis data secara deskriptif diketahui bahwa kemampuan numerik siswa kelas SMP Negeri di Kota Kendari tergolong rendah. Hal ini dapat dilihat pada Tabel 2 yang menunjukkan bahwa rata-rata kemampuan numerik siswa adalah 38,43 untuk seluruh sampel pernelitian. Hal ini juga telihat pada Tabel 3 bahwa dari seluruh siswa yang menjadi sampel penelitian, sebagian besar diantaranya merupakan siswa dengan kemampuan numerik rendah.

Dari keseluruhan siswa yang menjadi sampel penelitian terdapat hanya seorang siswa yang mempunyai kemampuan numerik tinggi, yaitu seorang siswa perempuan. Berdasarkan hasil analisis deskriptif sebagian besar siswa laki-laki memiliki kemampuan numerik rendah dan hanya terdapat sedikit siswa laki-laki dengan kemampuan numerik sedang, dan tidak terdapat satupun siswa laki-laki yang berkemampuan numerik tinggi.

Kemapuan numerik terbagi kedalam 3 indikator, yaitu pengetahuan dan pemahaman tentang bilangan, pengetahuan dan pemahaman tentang operasi, dan menerapkan pengetahuan dan pemahaman tentang bilangan dan operasi signifikan kemampuan numerik siswa laki-laki dan perempuan pada SMP Negeri di Kota Kendari. Di mana rata- rata kemampuan numerik siswa perempuan lebih tinggi dari pada rata-rata kemampuan numerik siswa laki-laki.

kedalam pengaturan komputasi. Perbandingan kemampuan dalam setiap indikator siswa laki-laki dan siswa perempuan dapat terlihat pada Tabel 4. Untuk indikator pengetahuan dan pemahaman tentang bilangan terlihat bahwa kemampuan numerik siswa perempuan lebih baik dari pada kemampuan numerik siswa laki-laki. Hal ini juga terjadi untuk indikator pengetahuan dan pemahaman tentang operasi dimana persentase kemampuan numerik siswa perempuan lebih tinggi dibandingkan dengan kemampuan numerik siswa laki-laki. Begitu pula untuk indikator menerapkan pengetahuan dan pemahaman tentang bilangan dan operasi kedalam pengaturan komputasi, terlihat bahwa kemampuan numerik siswa perempuan lebih tinggi dibandingkan dengan kemampuan numerik siswa lakilaki. Jadi untuk setiap indikator kemampuan numerik, terlihat bahwa kemampuan numerik siswa perempuan SMP Negeri di Kota Kendari lebih tinggi daripada kemampuan numerik siswa lakilaki.

Secara deskriptif dapat diketahui bahwa terdapat perbedaan kemampuan numerik siswa laki-laki dan perempuan. 
Agar lebih jelas dalam melihat perbedaan kemampuan numerik siswa laki-laki dan perempuan, maka dilakuan uji hipotesis. Sebelum dilakukan uji hipotesis, terlebih dahulu dilakukan uji prasyarat yaitu uji normalitas dan uji homogenitas. Berdasarkan uji normalitas data dengan menggunakan uji Kolmogorov-smirnov dengan bantuan SPSS diperoleh bahwa data berasal dari populasi yang tidak berdistribusi normal. Sedangkan untuk uji homogenitas data menggunakan uji Levene dengan bantuan SPSS diperoleh bahwa data varians data kemampuan numerik siswa laki-laki homogen dengan kemampuan numerik siswa perempuan.

Setelah dilakukannya uji prasyarat, selanjutnya dilakukan uji hipotesis. Karena data berasal dari populasi yang tidak berdistribusi normal, maka untuk uji hipotesis digunakan uji non parametrik yaitu uji Mann Whitney dengan bantuan SPSS. Hasil uji hipotesis data kemampuan numerik siswa laki-laki dan perempuan SMP Negeri di Kota Kendari diperoleh bahwa terdapat perbedaan yang signifikan kemampuan numerik siswa laki-laki dan perempuan pada SMP Negeri di Kota Kendari.

Dalam penelitian ini kemampuan numerik siswa perempuan lebih baik dari siswa laki-laki namun kemampuan numerik yang dimiliki siswa SMP di Kota Kendari tergolong rendah. Menurut Dagun (1992), terdapat beberapa perbedaan

\section{KESIMPULAN DAN SARAN}

Berdasarkan hasil analisis data dan pembahasan maka dapat disimpulkan sebagai berikut.

1. Kemampuan numerik siswa laki-laki di SMP Negeri di Kota Kendari ratarata 36,11, dari pengkategorian diperoleh 96,34\% atau 158 siswa mempunyai kemampuan numerik rendah dan 3,66\% atau 6 siswa yang mempunyai kemampuan numerik sedang kemampuan dalam bidang mata pelajaran seperti diterangkan berikut ini: Kaum wanita itu memperoleh skor yang lebih tinggi dibidang tertentu, seperti kemampuan verbal, sementara kemampuan spasialnya lebih rendah.

Berdasarkan hasil wawancara, beberapa faktor yang menyebabkan hasil tes kemampuan numerik siswa kelas VIII SMP Negeri di Kota Kendari tergolong rendah yaitu diantaranya siswa memang tidak memiliki dasar kemampuan numerik seperti hitung-menghitung yang baik. Masih banyak siswa kesulitan pada operasi yang melibatkan bilangan bulat, pecahan dan sifat matematika, sedangkan seperti yang kita ketahui pelajaranmatematika akanlebih mudah dipelajari oleh orangorangyang mempunyai kemampuan numerik yang tinggi. Hal ini dikarenakan sebagian besar materi yang ada dalam mata pelajaran matematika membutuhkan banyak penghitungan sehingga siswa yang mempunyai kemampuan numerik tinggi akan bekerja lebih baik dalam berhitung sedangkan siswa yang mempunyai kemampuan numerik rendah cenderung kesulitan dalam berhitung. Faktor lain yang menyebabkan rendahnya kemampuan numerik adalah siswa tidak mengulang materi yang telah diajarkan di sekolah, kebanyakan waktu siswa dihabiskan bermain dengan gadget mereka.

2. Kemampuan numerik siswa perempuan di SMP Negeri di Kota Kendari rata-rata 40, dari pengkategorian diperoleh $92,05 \%$ atau 197 siswa mempunyai kemampuan numerik rendah, $7,48 \%$ atau 16 siswa yang mempunyai kemampuan numerik sedang dan $0,46 \%$ atau 1 siswa mempunyai kemampuan numerik tinggi

3. Berdasarkan hasil analisis deskriptif dan inferensial menunjukkan bahwa 
terdapat perbedaan yang signifikan antara kemampuan numerik siswa laki-laki dan kemampuan numerik perempuan pada SMP Negeri di Kota Kendari. Di mana rata-rata kemampuan numerik siswa perempuan lebih tinggi dari pada ratarata kemampuan numerik siswa lakilaki.

Berdasarkan kesimpulan yang telah diuraikan, saran yang dapat diberikan adalah sebagai berikut:

\section{DAFTAR PUSTAKA}

Bobis, J. 1996. Visualisation and the development of number sense with kindergarten children. In J. Mulligan \& M. Mitchelmore (Eds.), Children's number learning. Adelaide: Australian Association of Mathematics Teachers and MERGA.

Burton, G. M. 1993. Number sense and operations: Addenda series, grades $K$-6.Reston, VA: National Council of Teachers of Mathematics.

Dagun, SM. 1992. Maskulin dan Feminim: Perbedaan Pria wanita dalam Fisiologi, Psikologi, Seksual, Karier dan Masa Depan. RinekaCipta. Jakarta.

Fennell, F., \& Landis, T.E. 1994. Number sense and operations sense. In C. A. Thornton \& N. S. Bley (Eds.), Windows of opportunity: Mathematics for students with special needs. Reston, VA: NCTM.

Gersten, R., \& Chard, D. 1999. Number sense: Rethinking arithmetic instruction for students with mathematical disabilities. The Journal of Special Education, 33: 18-28.

Herdiansyah, Haris. 2016. Gender dalam perspektif psikologi. Jakarta: Salemba Humanika.
1. Karena kemampuan numerik siswa SMP Negeri di Kota Kendari berada pada kategori rendah, maka perlu adanya solusi mengenai strategi, pendekatan, dan metode tertentu yang dapat meningkatkan kemampuan numerik siswa.

2. Perlu dilakukan penelitian lanjutan terhadap faktor-faktor yang mempengaruhi kemampuan numerik siswa rendah di SMP Negeri di Kota Kendari

Howden, H. 1989. Teaching number sense. The Arithmetic Teacher, 36: 6-11.

Leoni, Agustin. 2008. Super Tes IQ. Tangerang: PT Tangga Pustaka.

Reys,R.E.,\& Yang, D.C.1998.Relationship between computational performance and number sense among sixth- and eighth-grade students in Taiwan. Journal of Research In Mathematics Education, 29: 39-58

Reys, R., Reys, B., McIntosh, A., Emanuelsson, G., Johansson, B., \& Der, C.Y.1999. Assessing number sense of students in Australia, Sweden, Taiwan, and the United States. School Science and Mathematics, 99: 61-70.

Saleh, Andri. 2009. Number Sense, Belajar Matematika Selezat Cokelat. Bandung: Trans Media Pustaka

Siagian, Roida. 2013. Pengaruh Minat dan Kebiasaan Belajar Siswa Terhadap Prestasi Belajar Matematika. Jurnal formatif, 2(2): 122-131

Singh, Parmjit. 2008. An Assessment Of Number Sense Among Secondary School Students. Malaysia: MARA University of Technology

Sugiyono. 2007. Statistik Untuk Penelitian. Bandung: Alfabeta. 